\title{
Significance of English Language in India: Its Part in Contemporary National and Global Set Up
}

\author{
S. Rajkumar, P. Pandia Rajammal
}

\begin{abstract}
This paper is an endeavor to examine the significance of English writing in India, particularly, in setting of the present scenario. This foreign language influenced most of the region and culture in India.
\end{abstract}

Key words: Importance, English Language, influence, scenario, India.

\section{INTRODUCTION}

English language has played a significant role in our career life. Today it has turned into an image of people's desires for quality in training and full support in national and global life. The unmistakable effect of this nearness of English is that it is today being requested by everybody at the underlying phase of tutoring which further adds to the more elevated amount of instruction as well. Thus, the job and significance of English language in our national educational programs has expanded to a more prominent degree.

\section{SIGNIFICANCE OF ENGLISH LANGUAGE}

The present composing is an endeavor to feature the significance of English language in today's Indian culture and its role. The University Education Commission (1948) headed by Dr. S. Radha Krishnan prescribed : "English be considered in secondary school and colleges all together that we may stay in contact with the flood of regularly developing information. This would keep our confinement from the world and help us to exploit the more extensive reach of the English language." Two significant proposals in this regard were that English ought to be the vehicle of guidance in all colleges and it acts as an extraordinary unit for encouraging English as an expertise subject.

The National approach on Education (1968) kept up, "Uncommon accentuation should be laid on the investigation of English and other global dialects. World information is developing at a colossal pace, particularly in Science and Innovation. India must keep up this development, yet additionally make her very own huge commitment to it. For this reason, investigation of English has the right to be exceptionally strengthened."

As per Article 343 (2), the constitution of India accommodates the utilization of English for every single

Revised Manuscript Received on December 20, 2019.

* Correspondence Author

Mr. S. Rajkumar, English department, Kalasalingam Academy of Research and Education, Krishnankoil, Tamil Nadu, India. s.rajkumar@klu.ac.in

Email: xyz1@blueeyesintlligence.org

Dr. P. Pandia Rajammal, English department, Kalasalingam Academy of Research and Education, Krishnankoil, Tamil Nadu, India. pandiarajammal.p@klu.ac.in authority reason for a time of 15 years. The Union Government tried hard for the improvement of Hindi as the mode of articulation amid the time of 15 years. Be that as it may, it made genuine language discussion all through the nation. Subsequently the parliament prompted to precede English as the Official Language for an uncertain period. English becomes a compulsory language. It acts a worldwide connective language. The exchange and business correspondence has done between twostates or nations with the help of English language. The discourse between people of various nations is additionally led by English. In this way Jawahar Lal Nehru properly commented : "In the event that you push out English, does Hindi completely have its spot? I trust it will, I am certain it will. Yet, I wish to maintain a strategic distance from the risk of one binding together factor being pushed out without another bringing together factor completely having its spot. In that occasion there will be a hole, a break. The making of any such rest or hole must be maintained a strategic distance from no matter what. It is very essential to do as such in light of a legitimate concern for the solidarity of the nation. It is this that leads me to the end that English is probably going to have a significant spot in the predictable future."

The international language is language of global governmental issues, exchange, trade and business. In the expressions of F.G. French, "By mishaps of history and by the fast spread of mechanical advancement, science, innovation, worldwide trade, and by something like a blast in the speed and simplicity of movement and by every one of the variables which have separated wildernesses and constrained countries into closer between reliance, English has turned into a world language. It is the methods for global correspondence; there is no other."

In 1990, English become the medium of learning with utmost in schools. The present status of English nourished in the world. An investigation has proved that the language is used by 700 million people which is next just to the Chinese language. Be that as it may, though Chinese is limited generally to its sub-continents, English is utilized all over the world. It is the language of universal legislative issues exchange, trade and industry. We should understand that we are in the need of hour to learn English. Out of 10 people, one knows English, 75\% knows through the world's mail and also through world's papers, radio and magazines. Again it is one of the six authority dialects of U.N.O. It is the bond language of the all nations. English has made better understanding among the countries in the world which results in social exchange. It has encouraged versatility of educators and understudies starting with one nation for business. 
English has frequently been named as a window on the quick advancement of innovation and logical learning which turned as a continuous process. The Radhakrishnan University Education Commission watched, "It (English) is a language which is wealthy in writing humanistic, logical and specialized. In the event that under nostalgic urges we should surrender English, we would cut ourselves off from the living stream of regularly developing information. Unfit to approach this learning our benchmarks of grant would quick weaken and our support on the planet developments of thought would end up insignificant - for living countries must move with the occasions and should react rapidly to the difficulties of their environment. English is the main methods for keeping our segregation from the world." English acts as a window through which we can see the logical, innovative, farming, business and abstract advancements, occurring on the earth. F.G. French opined, "Any individual who can peruse English can stay in contact with the entire world without living his own home."

English is the mode of communication for learning. In spite of the fact that a multilingual nation, yet the majority of the information isn't yet accessible in Indian dialects. English plays as an official language in the administration of India. The Kothari Commission has appropriately focused on that English would assume an imperative job in advanced education as a significant library language. The commission kept up that no understudy ought to be viewed as equipped for a degree, specifically as higher studies, except if he has procured a sensible capability in English. As indicated by the Commission, "The ramifications of this (English as a library language) are twofold : all educators in advanced education ought to be basically bilingual as in they ought to have the option to instruct in the provincial language and in English and all understudies (Particularly post graduates) ought to have the option to pursue addresses and use perusing materials in the territorial language just as in English." Thus if a person expert in English he will be consider as a smart one in India.

The United Nations Organization (UNO) highlighted the fact that English is the most generally spoken dialects, yet in addition in light of the fact that the utilization of English has made the social and financial trade between individuals of various nations and societies for all intents and purposes conceivable. In a multi-religious and multi-social nation like India, individuals are with the dialects even though they are considered as outsiders or insiders with their regions. India is considered as post colonial country, English becomes an official language and it is used for both spoken and written communication. But anyway, English as an official language, it brings all continents and states under one roof by connecting through trading and business. English could be appropriately named as the Lingua Franca of India. In a nation like India as per 2001 survey, more than one hundred languages are spoken by people whereas 30 dialects are spoken by millions of local speakers. English can be considered as regular language which is utilized by speakers as a worthy vernacular language with abnormal amounts of appropriation over decades.

Historically, in India English as a language has done a significant job in media and instruction. Our Indian writers contribute a lot through English. In the world of science and

innovation English has turned into the main language in the Indian Education framework. Thus, English has got an international ID as a decent language to be used in all fields everywhere. Again with the developing significance of PCs in each field the English language has attained a progress. Other than tutoring and sorted out training frameworks pervasive in India all the examinations should be conducted in English language. In this manner English comprises a noteworthy segment of practically all aggressive examinations. David Graddol (2010) has mentioned, "All through India, there is an uncommon conviction among all stations and classes, in both rustic and urban zones, in the transformative intensity of English. English is seen as a helpful ability, however as an image of a superior life, a pathway out of neediness and abuse".

The difficulties of giving general access to English are noteworthy, and many will undoubtedly feel disappointed at the speed of advancement. Yet, we can't disregard the manner in which that the English language has risen as a ground-breaking specialist for change in India. English is acted as a symbol of superior image. It brings a tremendous change in our nation. It acted as a gateway for attaining social and monetary goals. Detecting the significance of the language at various dimensions Indian government has been taking different measures to provide it at the bottom level. Many model schools have been set up for proving this point. The specialists feel that to ready to get a handle on instruction at larger amounts, kids ought to be familiar with it as right on time as would be prudent.

\section{CONCLUSION}

In this manner, there is no disagreement for English may occupy a major position in the national and global situation. Mastering the language has become the need of the hour. Consequently it is essential that the students who should be the leaders of the country ought to accomplish capability in the language at any rate to a base degree with the goal.

\section{REFERENCES}

1. Kohli, A.L. Techniques of Teaching English. Page -12

2. Naik, J.P. A Students History of Education in India (1800-1973) Page 488

3. Kohli, A.L. Techniques of Teaching English, Page - 13

4. French F.G., Teaching English as an International Language, Page - 1

5. NCERT (2006) National Focus Group Position Paper on English, 1.4 Page $-1$

6. Graddol, David (2012). English Next India, British Council, Page -17

7. Baruah, T.C. (2001). The English Teacher"s Handbook. Page -15

8. Kohli, A.L. Techniques of Teaching English. Page -11

9. Kohli, A.L. Techniques of Teaching English, Page -12

10. Mowla, Shaik, Techniques of Teaching English, Page -11

11. Graddol. David (2012). English Next India. British Council, Page -15

12. Vallabi, J.E. Teaching of English, Principles and Practices. Page -11

\section{AUTHORS PROFILE}

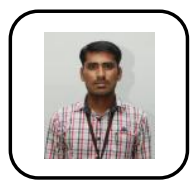

Mr. S. Rajkumar, M.A., M.Phil., graduated at Madurai Kamaraj University, Tamil Nadu, India, presented and published papers at International Conference, won the best teacher award, guided UG projects, working as an Assistant Professor at Kalasalingam Academy of Research and Education, Tamil Nadu, India. 
Dr. P. Pandia Rajammal, PhD., graduated at Madurai Kamaraj University, Tamil Nadu, India, presented papers at National and International Conference, published papers in Journal, Organied seminars and Guest Lectures, Guided PG projects and MPhil dissertations, working as an Assistant Professor at Kalasalingam Academy of Research and Education, Tamil Nadu, India. 